\title{
Bcl-2 Immunoexpression as Radiotherapy Response Predictor in Undifferentiated Nasopharynx Carcinoma
}

\author{
Beby S. Damayanti, Afiati, Abdul H. Hassan, Bethy S. Hernowo \\ Department of Pathology Anatomy \\ Faculty of Medicine, Padjadjaran University/Hasan Sadikin Hospital Bandung \\ Jl. Pasteur No. 38 Bandung 40161 Indonesia \\ Email: bebygigantara@gmail.com
}

\begin{abstract}
Nasopharyngeal carcinoma $(N P C)$ is an epithelial malignancy originating from the surface of the lateral and posterior wall of the nasopharynx. Bcl-2 is an oncoprotein that plays an important role in disrupting the process of apoptosis. Expression of Bcl-2 in biopsy samples of undifferentiated NPC also related to the nature of more aggressive tumor mass and unfavorable clinical radiotherapy response. The purpose of this study was to assess the relationship of Bcl-2 expression with radiotherapy response in undifferentiated NPC. The method of this study areusing 40 samples of paraffin blocks were diagnosed as undifferentiated $N P C$ by histopathologic examination with $H \& E$ staining. The samples were divided into 2 groups who respond and do not respond to radiotherapy. All samples examined by Bcl-2 immunohistochemistry and the expression willanalyzed and assess therelationship to radiotherapy response. Of the 40 cases of undifferentiated NPC show imunoekspresi Bcl-2 positive in 39 cases (97.5\%) and 1 case (2.5\%) negative from response group. The results of statistical analysis of the Bcl-2 obtained significant results with $p$ value <0.05 so we can conclude there is a relationship between Bcl-2 expression with radiotherapy response. Conclusion, Bcl-2 can be used as a predictor for the success of radiotherapy in undifferentiated $N P C$.
\end{abstract}

Keywords: Bcl-2, undifferentiated NPC, radiotherapy response 


\title{
Imunoekspresi Bcl-2 sebagai Prediktor Respons Radioterapi pada Karsinoma Nasofaring yang Tidak Berdiferensiasi
}

\author{
Beby S. Damayanti, Afiati, Abdul H. Hassan, Bethy S. Hernowo \\ Departemen Patologi Anatomi \\ Fakultas Kedokteran Unpad/RS Hasan Sadikin Bandung \\ Jl. Pasteur No. 38 Bandung 40161 Indonesia \\ Email: bebygigantara@gmail.com
}

\begin{abstract}
Abstrak
Karsinoma nasofaring (KNF) merupakan keganasan epitelial yang berasal dari permukaan dinding lateral dan posterior nasofaring. Bcl-2 merupakan onkoprotein yang sangat berperan dalam mengganggu proses apoptosis. Ekspresi Bcl-2 pada KNF yang tidak berdiferensiasi berhubungan dengan penghambatan proses apoptosis serta perpanjangan kelangsungan hidup sel. Adanya imunoekspresi Bcl-2 pada sampel biopsi KNF tidak berdiferensiasi berhubungan dengan sifat massa tumor yang lebih agresif dan respons klinis radioterapi yang kurang menguntungkan. Tujuan penelitian ini adalah untuk menilai hubungan imunoekpresi Bcl-2 dengan respons radioterapi pada KNF tidak berdiferensiasi. Penelitian ini menggunakan 40 sampel blok parafin yang telah didiagnosis sebagai KNF tidak berdiferensiasi secara histopatologi dengan pewarnaan H\&E. Sampel dibagi dalam dua kelompok, yaitu kelompok tidak berespons dan kelompok respons terhadap radioterapi sebanyak 20 sampel tiap kelompok. Kemudian dilakukan pewarnaan imunohistokimia Bcl-2, hasil imunoekspresi tersebut dinilai dan kemudian dihubungkan dengan respons radioterapi. Dari 40 kasus KNF tidak berdiferensiasi terdapat imunoekspresi Bcl-2 positif pada 39 kasus $(97.5 \%)$ dan 1 kasus $(2,5 \%)$ negatif dari kelompok respons. Hasil analisis statistik terhadap Bcl-2 diperoleh hasil yang signifikan dengan nilai $\mathrm{p}$ value $<0,05$ sehingga dapat disimpulkan terdapat hubungan antara imunoekspresi $\mathrm{Bcl}-2$ dengan respons radioterapi. Hasil penelitian ini mengungkapkan bahwa Bcl-2 dapat digunakan sebagai prediktor keberhasilan radioterapi pada KNF tidak berdiferensiasi.
\end{abstract}

Kata kunci: Bcl-2, KNF tidak berdiferensiasi, respons radioterapi 


\section{Pendahuluan}

Karsinoma nasofaring (KNF) merupakan keganasan epitelial yang berasal dari permukaan dinding lateral dan posterior nasofaring. ${ }^{1,2}$ Tidak seperti keganasan pada daerah kepala leher lainnya, karsinoma nasofaring sangat jelas menunjukkan hubungan prevalensi antara daerah dan ras. ${ }^{1,3}$ Karsinoma nasofaring merupakan penyebab kematian tersering pada sebagian besar populasi di Asia, Asia Tenggara dan Afrika. ${ }^{1,2,4,5}$

Rosai membagi KNF menjadi keratinizing squamous cell type, differentiated nonkeratinizing type dan undifferentiated non-keratinizing type, yang dibagi atas dua pola pertumbuhan yaitu Regaud type dan Schmincke type. ${ }^{2}$ Karsinoma nasofaring tidak berdiferensiasi tipe Schmincke sering sulit dibedakan dengan limfoma maligna. ${ }^{2}$

Diantara ketiga tipe ini, tipe undifferentiated merupakan jenis KNF yang paling sering ditemukan, sementara varian yang jarang ditemukan adalah tipe basaloid squamous cell carcinoma dan papillary adenocarcinoma. ${ }^{12,6}$

Insidensi yang tinggi KNF tidak berdiferensiasi dapat ditemukan di Hongkong dengan 1 dari 40 laki-laki menderita KNF sebelum berusia 75 tahun. Di Cina Selatan insidensi KNF tidak berdiferensiasi sangat tinggi dengan puncak insiden 20-30 kasus per 100.000 penduduk. ${ }^{1}$ Pada daerah dengan insidensi KNF tidak berdiferensiasi yang tinggi ditemukan hubungan erat antara pola makan dengan proses karsinogenesis. ${ }^{1}$ Tingkat kejadian KNF tidak berdiferensiasi antara orang-orang Tionghoa yang lahir di Amerika Utara lebih rendah dari pada mereka yang lahir di Cina Selatan, tapi masih tetap cukup tinggi bila dibandingkan dengan penduduk lokal. Temuan ini menunjukkan bahwa faktor genetik, etnis dan lingkungan memainkan peran penting dalam etiologi KNF tidak berdiferensiasi. ${ }^{7}$ Pada KNF tidak berdiferensiasi yang bersifat familial berhubungan dengan kerusakan lokus pada kromosom 3p khususnya pada regio 3p21.3 dan pada kromosom 9p21. ${ }^{7}$ Selain itu, konsumsi ikan asin dan makanan diawetkan yang mengandung volatile nitrosamines, terutama selama masa kanak-kanak, merupakan faktor karsinogenik penting pada $\mathrm{KNF}^{7}$ Indonesia, Philipina dan Vietnam merupakan negara dengan risiko sedang terhadap karsinoma nasofaring, ${ }^{1}$ sementara kasus KNF tidak berdiferensiasi yang tercatat di RS. Hasan Sadikin selama tahun 2010 sampai pertengahan tahun 2013 adalah sebanyak 320 kasus.

Karsinoma nasofaring tidak berdiferensiasi sangat berhubungan erat dengan infeksi Epstein Barr virus (EBV), virus ini menginfeksi hampir $95 \%$ populasi orang dewasa. ${ }^{8,}{ }^{9}$ EBV dapat bertransmisi melalui mulut kemudian secara primer menginfeksi dan mereplikasi epitel gepeng berlapis orofaring selama masa infeksi akut. ${ }^{8} \mathrm{EBV}$ merupakan gamma herpes virus yang mempunyai amplop dengan genom berupa DNA berantai ganda yang mengkode lebih dari 85 gen. ${ }^{10-13}$ Ada 2 jenis subtipe EBV yang dikenal menginfeksi manusia yaitu EBV tipe A dan EBV 


\section{Research Article}

tipe B yang distribusinya berbeda secara geografi. ${ }^{14}$ EBV tipe A adalah tipe yang paling sering ditemukan menginfeksi populasi di Asia, sedangkan EBV tipe B lebih sering ditemukan prevalensinya di daerah Afrika. ${ }^{14}$

$B$ cell lymphoma-2 merupakan onkoprotein yang sangat berperan dalam mengganggu proses apoptosis. ${ }^{15}$ Ekspresi dari $\mathrm{Bcl}-2$ pada KNF yang tidak berdiferensiasi berhubungan dengan penghambatan proses apoptosis serta perpanjangan kelangsungan hidup sel. ${ }^{16,17} \mathrm{~B}$ cell lymphoma-2 merupakan proto-onkoprotein manusia yang dapat ditemukan pada membran amplop inti, retikulum endoplasma dan membran bagian luar mitokondria. ${ }^{3}$ Bila dibandingkan dengan keganasan pada daerah kepala dan leher lainnya, maka ditemukan ekspresi Bcl-2 dengan persentase yang sangat tinggi pada KNF yang tidak berdiferensiasi. ${ }^{3}$ Meningkatnya regulasi Bcl2 mRNA pernah ditemukan pada beberapa penelitian terhadap biopsi KNF tidak berdiferensiasi. ${ }^{15,18}$

Kouvidou dkk melakukan pemeriksaan imunohistokimia Bcl-2 terhadap KNF yang ditemukan tereskpresi positif pada 11 dari 44 kasus $(25 \%) .{ }^{19}$ Hubungan antara ekspresi Bcl-2 dengan tipe histopatologis pada penelitian ini ditemukan ekspresi Bcl-2 positif pada 5 dari 15 kasus non-keratinizing squamous cell carcinoma, dan 6 dari 16 kasus undifferentiated carcinoma, 13 kasus keratinizing squamous cell carcinoma keseluruhannya menunjukkan ekspresi Bcl-2 negatif. Tipe pewarnaan Bcl-2 pada sel-sel tumor dapat dilihat pada sitoplasma dengan intensitas pewarnaan yang lebih kuat bila dibandingkan dengan infiltrasi sel-sel limfosit yang terwarnai. ${ }^{19}$ Pada KNF tidak berdiferensiasi dengan EBV positif ditemukan ekspresi Bcl-2 yang lebih tinggi bila dibandingkan dengan KNF EBV negatif.

Radioterapi tetap merupakan modalitas pengobatan utama untuk KNF tidak berdiferensiasi. Tujuan terapi radiasi adalah mengeradikasi tumor in vivo dengan memberikan sejumlah dosis radiasi yang diperlukan secara tepat pada daerah massa tumor yang menjadi target radiasi, tanpa menimbulkan kerusakan berlebihan pada jaringan sehat di sekitarnya. ${ }^{20,} 21$ Harapan pemberian terapi radiasi adalah memperpanjang angka kelangsungan hidup dan perbaikan kualitas hidup pasien. ${ }^{21}$ Radiosensitivitas sel tumor tergantung pada banyak faktor, diantaranya diferensiasi sel tumor dapat mempengaruhi radiosensitivitas. ${ }^{22}$

Meningkatnya regulasi Bcl-2 pada KNF tidak berdiferensiasi berhubungan erat dengan sifat agresif massa tumor yang pertumbuhannya melibatkan kelenjar getah bening, dapat bermetastasis, rekurensi tinggi serta tingkat kelangsungan hidup yang menurun pada pasien KNF. ${ }^{3}$, 


\section{Research Article}

\section{Metode}

Penelitian ini merupakan penelitian analitik komparatif dengan rancangan penelitian retrospektif secara case control non disain khusus, analisis kategorik tidak berpasangan yang membandingkan skor Bcl-2 dari semua subjek penelitian yang memenuhi kriteria inklusi. Subjek penelitian terdiri atas dua kelompok, yaitu kelompok tidak respons dan kelompok respons masing-masing 20 subjek tiap kelompok.

Penelitian diawali dengan pengumpulan data kasus KNF tidak berdiferensiasi yang telah diperiksa secara histopatologis di Bagian Patologi Anatomi Rumah Sakit Dr. Hasan Sadikin Bandung, kemudian dicatat nomor blok parafin, nomor rekam medis, dan umur. Berdasarkan data yang ada, berkas rekam medik dikumpulkan dan dipilih kasus yang mendapat radioterapi komplit sebanyak 33x, kemudian dicari blok parafinnya. Blok parafin dari penderita dibuat dua buah preparat, preparat pertama dibuat dengan pulasan hematoxylin eosin (HE), preparat kedua dilakukan pulasan imunohistokimia Bcl-2 dan seluruhnya diperiksa dan dinilai dengan menggunakan mikroskop cahaya merk Olympus CX21 LED dengan perbesaran lensa objektif $4 \mathrm{x}, 10 \mathrm{x}, 40 \mathrm{x}$.

Kriteria respons radioterapi dilihat dari data rekam medis penderita, pada penelitian ini penderita disebut berespons bila memenuhi kriteria respons komplit (tumor primer hilang 100\%) dan respons sebagian (bila pengecilan besar tumor $\geq 50 \%$ ). Penderita disebut tidak berespons jika memenuhi kriteria penyakit progresif. ${ }^{20}$

Setelah dilakukan prosedur di atas, selanjutnya dilakukan penilaian hasil pulasan. Hasil pulasan imunohistokimia Bcl-2 dibandingkan dengan kontrol positif berupa sediaan tonsillitis. ${ }^{23-}$ ${ }^{25}$ Imunoekspresi Bcl-2 dinyatakan positif bila sitoplasma sel tumor terwarna cokelat. ${ }^{25}$ Pada massa tumor intensitas pewarnaan Bcl-2 terlihat lebih kuat dan dominan bila dibandingkan dengan intensitas Bcl-2 yang terlihat pada sel limfosit normal. ${ }^{26}$ Perhitungan sel tumor yang mempunyai imunoekspresi Bcl-2 dilakukan dalam 100 sel diambil dengan memilih area yang representatif pada massa tumor, dengan menggunakan lensa objektif pembesaran 40x secara random sampling diambil 10 lapangan pandang. Hasil penghitungan dilaporkan dengan persentase sel terpulas (distribusi) serta intensitas pulasan. ${ }^{27,}{ }^{28}$ Penghitungan sel yang imunoreaktif tersebut dikerjakan dengan menggunakan mikroskop cahaya merk Olympus tipe CX21 LED.

Setiap kasus sediaan penelitian diberi skor persentase pada sel tumor yang terpulas dengan pulasan imunohistokimia LMP1 dan Bcl-2 seperti yang ditampilkan pada Tabel 1 . 
Tabel 1 Evaluasi Ekspresi LMP-1 dan Bcl-2 ${ }^{29}$

\begin{tabular}{llll}
\hline Skor & Distribusi sel yang positif & Skor & Intensitas \\
\hline 0 & Tidak ada sel yang positif & 0 & $\begin{array}{l}\text { Tidak ada warna } \\
\text { Ada warna, intensitas lemah } \\
\text { (coklat muda) }\end{array}$ \\
2 & Sel yang positif $\leq 10 \%$ & 1 & $\begin{array}{l}\text { Ada warna intensitas sedang } \\
\text { (coklat) }\end{array}$ \\
3 & $\begin{array}{l}\text { Sle yang positif } \\
11-50 \%\end{array}$ & 2 & Ada warna intensitas kuat (coklat \\
& Sel yang positif & 3 &
\end{tabular}

Analisis statistik pada penelitian ini adalah analisis bivariabel. Analisis bivariabel menggunakan uji statistik Chi-square test dengan alternatif uji Exact Fisher. Data dalam penelitian ini meliputi usia, jenis kelamin, kelompok tidak respons dan kelompok respons terhadap radioterapi dan kategori imunoekspresi Bcl-2. Untuk menguji hipotesis penelitian ini maka dilakukan uji Chi-square test untuk membuktikan apakah terdapat hubungan antara imunoekspresi Bcl-2 dengan respons radioterapi.

Skor akhir distribusi dikalikan intensitas adalah 0-12 dengan pengelompokan sebagai berikut:

- $0 \quad=$ Negatif $(\mathrm{N})$

- 1-2 = Positif lemah (PL)

- $3-4=$ Positif sedang (PS

- 6-12 = Positif kuat (PK)

Hasil

Karakteristik subjek penelitian tercantum pada Tabel 2. Gambaran imunoekspresi Bcl-2 positif kuat dan imunoekspresi Bcl-2 negatif ditampilkan pada Gambar 1 dan 2.

Tabel 2 Karakteristik Dua Kelompok Penelitian

\begin{tabular}{lccc}
\hline \multirow{2}{*}{ Karakteristik } & \multicolumn{2}{c}{ Kelompok } & \multirow{2}{*}{ P Value } \\
\cline { 2 - 3 } & $\begin{array}{c}\text { Tidak Respons } \\
\mathrm{n}=20\end{array}$ & $\begin{array}{c}\text { Respons } \\
\mathrm{n}=20\end{array}$ & \\
\hline Jenis Kelamin & $13(65,0 \%)$ & $12(60,0 \%)$ & 0.744 \\
Pria & $7(35,0 \%)$ & $8(40,0 \%)$ & \\
Wanita & $44,3500 \pm 10.25606$ & $39,7000 \pm 14.16110$ & 0,242 \\
Umur & & & \\
\hline
\end{tabular}




\section{Research Article}

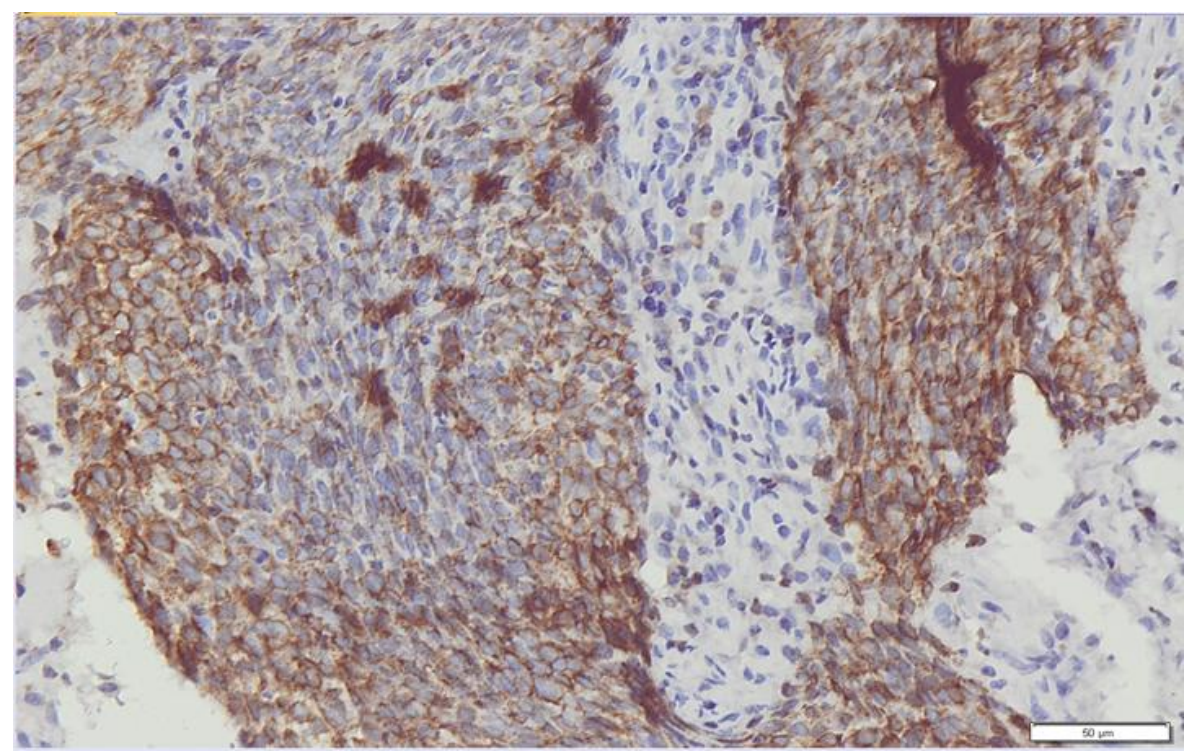

Gambar 1 Imunoekspresi Bcl-2 (+) Kuat, perbesaran 200X

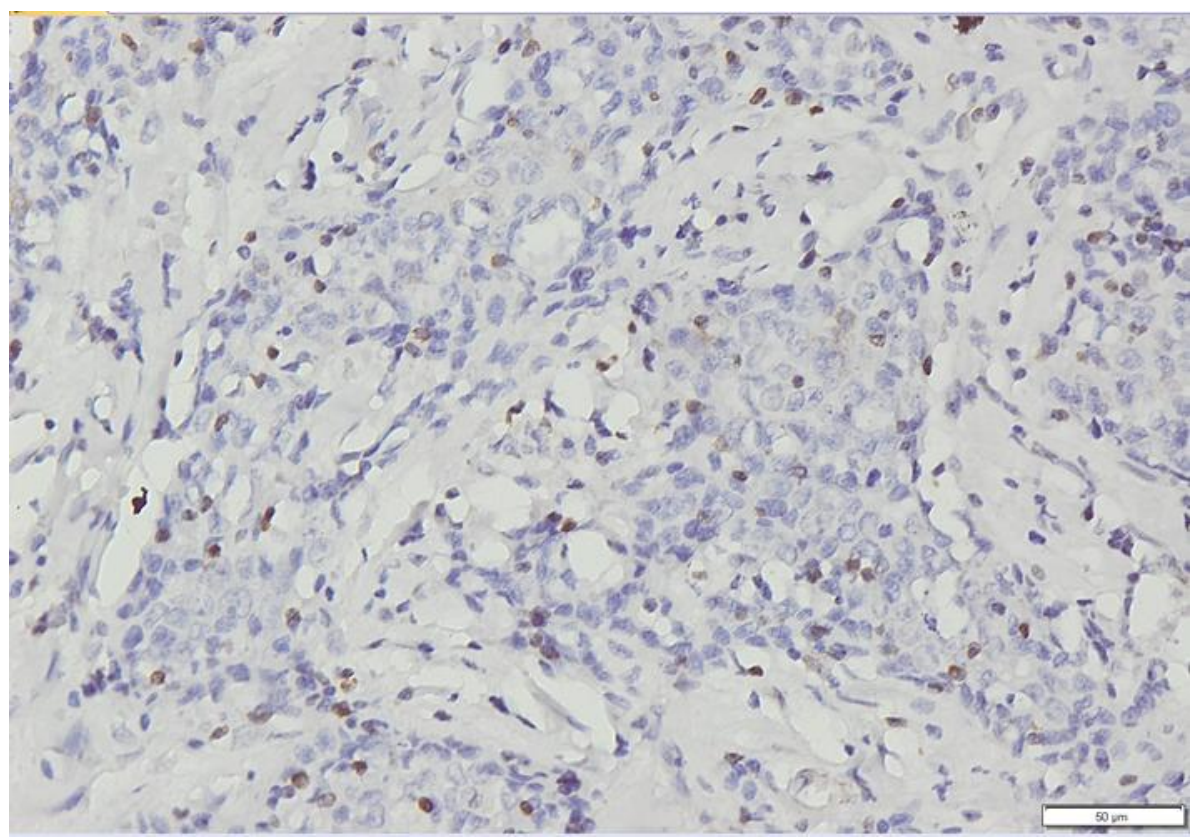

Gambar 2 Imunoekspresi Bcl-2 (-), perbesaran 200X

Analisis hasil penelitian dibantu oleh perhitungan statistik. Kasus KNF tidak berdiferensiasi yang tidak reaktif terhadap antibodi Bcl-2 digabung dengan kasus yang memberikan imunoekspresi lemah sampai sedang, dan kasus yang memberikan imunoekspresi kuat dinilai tersendiri agar dapat dilakukan perhitungan statistik menggunakan analisis uji ChiSquare alternatif uji Exact Fisher seperti terlihat pada Tabel 3. 


\section{Research Article}

Hasil analisis statistik dari Tabel 3 dengan menggunakan uji Chi-square alternatif uji Exact Fisher menunjukkan nilai $\mathrm{p}$ value 0,024 atau $\mathrm{p}<0,05$ sehingga dapat disimpulkan terdapat hubungan antara imunoekspresi Bcl-2 dengan respons radioterapi pada KNF tidak berdiferensiasi.

\section{Tabel 3 Hubungan antara Imunoekspresi Bcl-2 dengan Respons Radioterapi pada KNF Tidak Berdiferensiasi}

\begin{tabular}{|c|c|c|c|c|c|c|c|c|}
\hline & \multirow{3}{*}{ Variabel } & \multicolumn{4}{|c|}{ Kelompok } & \multirow{3}{*}{ Total $\sum$} & \multirow{3}{*}{$\%$} & \multirow{3}{*}{ Statistik } \\
\hline & & \multicolumn{2}{|c|}{ Tidak Respons } & \multicolumn{2}{|c|}{ Respons } & & & \\
\hline & & $\mathrm{n}$ & $\%$ & $\mathrm{n}$ & $\%$ & & & \\
\hline \multirow{2}{*}{ Bcl-2 } & $\begin{array}{l}\text { Negatif - } \\
\text { Positif Sedang }\end{array}$ & 0 & 0 & 10 & 50 & 10 & 25 & $p=0.024 * *$ \\
\hline & Positif Kuat & 20 & 100 & 10 & 50 & 30 & 75 & \\
\hline Total & & 20 & 100 & 20 & 100 & 40 & 100 & \\
\hline
\end{tabular}

\section{Keterangan:}

untuk data kategorik p dihitung berdasarkan uji statistika Chi-Square alternatif uji Exact Fisher.

Nilai kemaknaan berdasarkan nilai $\mathrm{p} \leq 0,05$.

Tanda $* *$ menunjukkan signifikan atau bermakna secara statistika

\section{Diskusi}

Lokasi anatomi dari KNF tidak berdiferensiasi cukup sulit sehingga standar terapi utama pengobatan pasien dengan KNF tidak berdiferensiasi adalah dengan radioterapi, sedangkan tindakan operasi biasanya hanya terbatas untuk pengambilan sampel biopsi. ${ }^{30}$ Tindakan bedah tidak memainkan peran utama dalam mengobati KNF tidak berdiferensiasi namun dapat membantu dalam proses pengangkatan kelenjar getah bening yang membesar pada penderita $\mathrm{KNF}^{30}$

Terapi utama di RS.Hasan Sadikin untuk KNF tidak berdiferensiasi adalah radioterapi. Terapi ini bertujuan untuk mengeradikasi tumor in vivo dengan memberikan sejumlah dosis radiasi yang diperlukan secara tepat pada daerah massa tumor yang menjadi target radiasi, tanpa menimbulkan kerusakan berlebihan pada jaringan sehat di sekitarnya. Meskipun KNF tidak berdiferensiasi merupakan tumor yang bersifat radiosensitif, namun ditemukan kegagalan terapi yang cukup tinggi disebabkan perilaku metastasis dari massa tumor. ${ }^{30}$ Harapan pemberian radioterapi adalah memperpanjang angka kelangsungan hidup dan perbaikan kualitas hidup pasien. ${ }^{6,22,31}$ Identifikasi faktor indikator prognostik yang lebih akurat dan berkorelasi dengan hasil terapi sangat diperlukan dan dapat membantu dalam mengidentifikasi pasien KNF tidak berdiferensiasi yang memiliki risiko kekambuhan lokoregional dan metastasis jauh. ${ }^{30}$

Kasus KNF tidak berdiferensiasi yang memiliki catatan rekam medik lengkap, dan mendapatkan radioterapi lengkap sebanyak 33x serta tersedia blok parafinnya ditemukan 


\section{Research Article}

sebanyak 40 kasus yang seluruhnya kemudian dipergunakan untuk penelitian ini. Insidensi KNF tidak berdiferensiasi menunjukkan kurva bimodal, dengan puncak pertama antara usia 15 tahun 25 tahun, dan puncak lainnya antara usia 60-69 tahun, dengan jumlah penderita pria lebih banyak bila dibandingkan dengan wanita. Terdapat hubungan prevalensi antara wilayah daerah dan ras. ${ }^{1,2}$

Penelitian yang dilakukan oleh Yip dkk menunjukkan pada sebanyak 42 dari 64 kasus (66\%) KNF tidak berdiferensiasi dengan EBV positif ditemukan adanya imunoekspresi Bcl$2 .{ }^{18}$ Imunoekspresi Bcl-2 lebih sering ditemukan pada pasien KNF tidak berdiferensiasi di Asia, khususnya China, bila dibandingkan dengan pasien yang berasal dari Afrika atau Kaukasia. ${ }^{18}$ Berdasarkan hasil yang didapat pada penelitian ini terhadap 40 kasus KNF tidak berdiferensiasi dari kelompok respons dan tidak respons ditemukan adanya imunoekspresi Bcl-2 pada 39 dari 40 kasus $(97,5 \%)$ penelitian.

Overekspresi Bcl-2 banyak ditemukan pada berbagai jenis tumor, pada KNF tidak berdiferensiasi overekspresi Bcl-2 berhubungan dengan rekurensi dan progresivitas yang disertai dengan prognosis yang buruk dan keganasan yang invasif. ${ }^{32} \mathrm{Hal}$ ini dapat mempengaruhi respons pasien terhadap radioterapi dan kemoterapi. ${ }^{32}$ Pada penelitian ini ditemukan hubungan yang bermakna antara imunoekspresi Bcl-2 dengan respons radioterapi.

Penelitian yang dilakukan oleh Sarac dkk secara in vitro tentang pengekalan sel B leukemia/lymphoma-2 oleh EBV ditemukan adanya peningkatan ekspresi Bcl-2 yang dapat ditemukan pada sel epitel secara in vitro. ${ }^{33}$ B cell lymphoma-2 dapat menjadi tumor biomarker yang dapat menentukan prognosis. ${ }^{34}$ Penelitian terkini terhadap ekspresi Bcl-2 pada KNF tidak berdiferensiasi dapat mempunyai nilai prognostik. Fendri dkk telah melakukan penelitian terhadap 89 kasus KNF tidak berdiferensiasi pada pasien-pasien di Tunisia, untuk mendeteksi ekspresi mRNA Bcl-2 pada KNF tidak berdiferensiasi dengan menggunakan metode $R T P C R$, hasilnya ditemukan level mRNA Bcl-2 yang meningkat pada tumor nasofaring stadium lanjut, mRNA Bcl-2 juga berhubungan dengan keterlibatan kelenjar getah bening dan metastasis jauh. Analisis kelangsungan hidup menunjukkan pasien KNF tidak berdiferensiasi dengan Bcl-2 positif mempunyai disease free survival dan overall survival lebih rendah. ${ }^{34}$

Chen dkk melakukan penelitian terhadap 105 kasus KNF tidak berdiferensiasi yang memperoleh radioterapi dosis tinggi. Pada penelitian tersebut dilakukan analisis tentang hubungan imunoekspresi Bcl-2 dengan stadium TNM dan disease-specific survival. ${ }^{35}$ Pasien KNF tidak berdiferensiasi stadium III dan IV yang tidak disertai dengan adanya imunoekspresi Bcl-2 mempunyai disease-free survival yang lebih baik. ${ }^{35}$ Pada pasien KNF tidak berdiferensiasi stadium IV dengan imunoekspresi Bcl-2 yang negatif ditemukan disease-free survival yang lebih 


\section{Research Article}

baik bila dibandingkan dengan pasien KNF tidak berdiferensiasi stadium III dengan imunoekspresi Bcl-2 yang positif. Secara keseluruhan pasien-pasien dengan massa tumor yang mempunyai imunoekspresi Bcl-2 cenderung memiliki 5 years survival rate yang lebih buruk. ${ }^{35}$

\section{Simpulan}

Terdapat hubungan antara imunoekspresi Bcl-2 dengan respons radioterapi pada KNF tidak berdiferensiasi. Imunoekspresi Bcl-2 dapat dijadikan sebagai faktor prediksi terhadap keberhasilan radioterapi, sehingga dapat disimpulkan semakin tinggi ekspresi Bcl-2 pada KNF tidak berdiferensiasi maka semakin tidak berespons massa tumor tersebut terhadap radioterapi.

\section{Daftar Pustaka}

1. Chan JKC, Bray F, McCarron P, Foo W, Lee AWM, Yip T, et al. Nasopharyngeal carcinoma. In: Barnes L, Eveson JW, Reichart P, Sidransky D, editors. Pathology \& genetics head and neck tumours. Lyon: World Health Organization Classification of Tumours, IARC Press; 2005. p. 81-97.

2. Respiratory tract: nasal cavity, paranasal sinuses, and nasopharynx, larynx and trachea, lung and pleura. In: Rosai J, editor. Rosai and Ackerman's Surgical Pathology 1. 10 ed. British Library Cataloguing in Publication Data Mosby-Elsevier; 2011. p. 291- 300.

3. Tulalamba W, Janvilisri T. Nasopharyngeal carcinoma signaling pathway: an update on molecular biomarkers. Int J Cell Biol. 2012; 594-681.

4. Adegboyega PA. Viruses and cancer. African J Clin Exp Microbiol. 2012; 13:1-18.

5. Gullo C, Low WK, Teoh G. Association of Epstein-Barr virus with nasopharyngeal carcinoma and current status of development of cancer-derived cell lines. Ann Acad Med. 2008;37(9):769-77.

6. Quon H. Cancer of the head and neck. In Abeloff MD, Armitage JO, Niederhuber JE, Kastan MB, McKenna WG, editors. Abeloff's Clinical Oncology. 4 ed. Churchill-Livingstone, Elsevier; 2008. p. 1177-228.

7. Jia WH, Luo XY, Feng BJ, Ruan HL, Bei JX, Liu WS, et al. Traditional Cantonese diet and nasopharyngeal carcinoma risk: a large-scale case-control study in Guangdong, China. BMC cancer. 2010;10:446.

8. Korcum AF, Özyar E, Ayhan A. Epstein-Barr virus genes and nasopharyngeal cancer. Turkish J Cancer. 2006;36:97-108.

9. Sengupta S, den Boon JA, Chen IH, Newton MA, Dahl DB, Chen M, et al. Genome-wide expression profiling reveals EBV-associated inhibition of MHC class I expression in nasopharyngeal carcinoma. Cancer Res. 2006;66(16):7999-8006.

10. Dar WA, Sugden B. Epstein-Barr Virus As A Pathogen. In: Khalili K, Jeang KT, editors. Viral Oncology Basic Science and Clinical Application. New Jersey: Wiley- Blackwell; 2010. p. 425-51.

11. Gulley ML. Molecular diagnosis of Epstein-Barr virus-related disease. J Mol Diagn. 2001;3:1-10.

12. Kumar P, Saha A, Robertson ES. Epstein-Barr virus hijacks cell-cycle machinery. Microbe. 2010;5:251-6.

13. Masmoudi A, Toumi N, Khanfir A, Kallel-Slimi L, Daoud J, Karray H, et al. Epstein-Barr virus-targeted immunotherapy for nasopharyngeal carcinoma. Cancer Treat Rev. 2007;33(6):499-505.

14. Thompson MP, Kurzrock R. Epstein-Barr virus and cancer. Clin Cancer Res. 2004;(10):803-21.

15. Chou J, Lin YC, Kim J, You L, Xu Z, He B, et al. Nasopharyngeal carcinoma--review of the molecular mechanisms of tumorigenesis. Head \& neck. 2008;30(7):946-63.

16. Vera-Sempere FJ, Burgos JS, Botella MS, Morera C. Immunohistochemical expression of Bcl-2 oncoprotein in EBV-associated nasopharyngeal carcinoma correlated to histological type and survival. Histol and histopathol. 1997;12(1):9-18.

17. Yenn Lu JJ, Yang Chen J, Ying Hsu T, Yu WCY, Su IJ, Yang CS. Cooperative interaction between Bcl-2 and Epstein-Barr virus latent membrane protein 1 in the growth transformation of human epithelial cells. J Gen Virol. 1997;78:2975-85.

18. Yip KW, Shi W, Pintilie M, Martin JD, Mocanu JD, Wong D, et al. Prognostic significance of the Epstein-Barr virus, p53, Bcl-2, and survivin in nasopharyngeal cancer. Clin Cancer Res. 2006;12(19):5726-32.

19. Kuovidou C, Kanavaros P, Papaioannou D, Stathopaoulus E, Sotsiou F, Datseris G, et al. Expression of bcl-2 and p53 proteins in nasopharyngeal carcinoma. Abscense of correlation with the presence of EBV encoded EBER1-2 transcripts and latent membrane protein 1. J Clin Pathol: Mol Pathol. 1995;48:17-22. 


\section{Research Article}

20. Asroel HA. Penatalaksanaan radioterapi pada karsinoma nasofaring. Fakultas Kedokteran Bagian Ilmu Telinga, Hidung danTenggorokan Universitas Sumatera Utara; 2002.

21. Abdullah AA, Sekarutami SM. Kanker Nasofaring. In: Nuranna L, Reksodiutro AH, Gondhowiharjo S, editors. Pedoman tatalaksana kanker. 1 ed. Jakarta: Badan Penerbit FKUI; 2010. p. 27-38.

22. Lee N, Colevas AD, Fu KK. Head and Neck Tumors: Cancer of the nasopharynx. In: Hoppe RT, Phillips TL, Roach M, editors. Leibel and Phillips text book of radiation oncology. 3 ed. Philadelphia: Saunders Elsevier; 2010. p. 245-55.

23. Viral oncology basic science and clinical applications. New Jersey: Wiley-Blackwell; 2010.

24. Monoclonal mouse anti-Epstein-Barr Virus LMP cones CS.1-4. In: DakoCytomation, editor. Denmark 2004

25. Monoclonal mouse anti-human BCL2 oncoprotein clone 124. In: DakoCytomation, editor. Denmark 2004.

26. Vera-Sempere FJ, Burgos JS, Botella MS, Morera C. Immunohistochemical expression of Bcl-2 oncoprotein in EBV associated nasopharyngeal carcinoma correlated to histological type and survival. Histol Histopathol. 2001;12:9-18.

27. Choudhury RK, Yagle KJ, Swanson PE, Krohn KA, Rajendran JG. A robust automated measure of average antibody staining in immunohistochemistry images. J Histochem Cytochem. 2010;58:95-107.

28. Van Diest PJ, Van Dam P, Henzen-Longmans SC, Berns E, Van der Burg MEL, Green J, et al. A scoring system for immunohistochemical staining : consensus report of the task force for basic research of the EORTC-GCCG. J Clin Pathol. 1997;50:801-4.

29. Kasprzak A, Spachacz R, Wachowiak J, Stefañska K, Zabel M. Epstein-Barr virus (EBV) infection in B-cell nonHodgkin's lymphomas in children: virus latency and its correlation with CD21 and CD23 molecules. Folia Histochem Cytobiol. 2007;45:169-79.

30. Liu MT HC, Chang TH, Lin JP, Huang CC, Wang AY. Prognostic factors affecting the outcome of nasopharyngeal carcinoma. Jpn J Clin Oncol. 2003;33:501-8.

31. Mould RF, Tai THP. Nasopharyngeal carcinoma: treatments and outcomes in the 20th century. Br J Radiol. 2002;75:307-39.

32. Li SS, Tang QL, Wang SH, Chen YH, Liu JJ, Yang XM. Simultaneously targeting Bcl-2 and Akt pathways reverses resistance of nasopharyngeal carcinoma to TRAIL synergistically. Tumori. 2011;97(6):762-70.

33. Sarac S, Akyol MU, Kanbur B, Poyraz A, Akyol G, Yilmaz T, et al. Bcl-2 and LMP1 expression in nasopharyngeal carcinomas. Am J Otolaryngol. 2001;22(6):377-82.

34. Fendri A, Kontos C, Khabir A, Mokdad-Gargouri R, Ardavanis A, Scoralis A. Quantitative analysis of BCL2 mRNA expression in nasopharyngeal carcinoma: an unfavourable and independent prognostic factor. Tumour biol. 2010;5:391-9.

35. Chen MK, Lai JC, Chang CC, Chang JH, Chang YJ, Chen HC. Prognostic impact of bcl-2 expression on advanced nasopharyngeal carcinoma. Head \& neck. 2008;30(8):1052-7. 